\title{
Crossectional Study on the Prevalence And Economic Significance of Hydatidosis in Slaughtered Ruminants at Debrezeit Elfora Export Abattoir Oromia Region Eastern Showa Zone, Ethiopia
}

\author{
Shimeles Abegaz* and Awole Mohammode \\ School of Veterinary Medicine, Wollo University, Ethiopia
}

Received: March 01, 2018; Published: April 03, 2018

*Corresponding author: Shimeles Abegaz, School of Veterinary Medicine, Wollo University, Ethiopia, P.O. Box 1145, Dessie Amhara, Ethiopia,

\begin{abstract}
An abattoir survey based study was conducted between November 2011 and March 2012 period, to determine the prevalence and economic significance of hydatidosis in slaughtered ruminants. During the study, Debrezeit Elfora export abattoir were visited twice a week to examine the internal organs (livers, lungs, kidney and hearts) for the presence of hydatid cysts in ruminants and total 203 cattle, 384 sheep and 547 goats were examined for the presence of hydatid cyst. It was found that $42.86 \%$ of cattle, $7.03 \%$ of sheep and $4.39 \%$ of goats were infected with this disease. The cysts in cattle, sheep and goats $(\mathrm{P}<0.05)$ were found mostly in lungs $(41.4 \%, 7.03 \%$ and $4.39 \%)$ respectively, whereas the liver is second affected organ in all the three species of animals ( $\mathrm{p}<0.05 \%)$. In addition to this, six, two and one kidneys in cattle, sheep and goats respectively and one heart in cattle only were infected with hydatid cyst. In this study, the prevalence of hydatidosis and the number of cysts in ruminants were found different when the cattle, sheep and goats examined were stratified based on their age and body condition.

The prevalence and the number of cysts was high in those animals that has poor body condition and low in those animals having good body condition $(\mathrm{P}<0.05)$, but there is no significant difference $(\mathrm{P}>0.05 \%)$ between young and adult ruminants based on age. The economic loss in the value of the income due to carcass weight loss and because of the discarded organs (lung, liver, kidney and heart) annually as a result of hydatidosis was estimated to be 693,987.81 ETB for cattle, 600,465.2 ETB for sheep and 257, 790.19 ETB for goats. The minimum total loss for all infected animals was determined to be 1,552, 243.2 ETB based on the market prices at Debrezeit in the year 2012.So that application of proper meat inspection was recommended to reduce such situations.
\end{abstract}

Keywords: Debrezeit; Economic Loss; Elfora; Hydatidosis; Prevalence; Ruminants

\section{Introduction}

Ethiopia has the largest livestock population and the largest number of indig enous cattle breeds in Africa, with an estimated number of large and small ruminant populations of 40.3 million cattle, 20.7 million sheep and 16.3 million goats (CSA, 2004). However, this great potential was not properly exploited mainly due to prevailing traditional management and rampant diseases distribution. Both endoparasite and ectoparasite infestation represents a major drawback on livestock production in the tropics Ogurinade and Adgegole [1]. Hydatidosis (cystic echnococcusis) was one of the most important parasitic diseases of ruminants responsible for huge economic losses due to reduction in carcass weight gain and condemnation of Organs Hubber et al. [2].
Hydatidosis is a zoonotic parasitic disease caused by larval stages (hydatid cysts) of cestodes belonging to the genus Echinococcus and the family Taeniidae Thompson and McManus [3]. Hydatid cyst, which is the larval stage of Echinococcus, is a bladder like cyst formed in various organs and tissues following the growth of the oncospheres of an Echninoccus tape worm in that specific organ or tissue Martinma [4].

The larval stage develops in a very wide range of intermediate host including man and the adult stage is found in carnivores Urqhart et al. [5]. Echinococcosis /Hydatidosis/is endemic in sheep and cattle raising areas worldwide. Especially E. grnulosus has a worldwide geographical distribution and occurs in all countries. 
High prevalence is found in parts of Eurasia, Africa, Australia and South America. E. multilocularis is also distributed in the Northern hemisphere, including endemic regions in Central Europe, most of Northern and Central Eurasia, parts of North America and in Northern Africa (Tunisia) Eckert et al. [6,7]. The life cycle of hydatidosis involves two mammalian hosts. The adult cestode inhibits the small intestine of carnivores (definitive host) and produces eggs containing infective oncosphers. Cestodes segments, proglotids containing eggs (free eggs) released from the intestinal tract of final host in to the environment.

After ingestion of eggs by food animals (intermediate host) such as cattle, sheep, goats, swine and camel, the larval stage (metacestod), develops in the visceral organs typically the matured metacestod produces numerous protoscolices, each having the potential to develop into an adult cestode after being ingested by the carnivore definitive host. Accidentally, ingestion of the eggs Thompson and Mc Manus [8] infects humans and other aberrant hosts. In human beings hydatidossis is also found worldwide and cause serious public health problems especially E.granulosus is more common and E. mutilocularis is the most virulent Permin and Hansen [9]. From several regions of the world there are alarming indications of increasing human health risks caused by echinococcosis Eckert et al. [6]. There were yet no simple and satisfactory techniques available for ante-mortem diagnosis of echinococcosis in domestic or wild animals such as immunodiagnostic. Hydatidosis in food animals is detected by post-mortem examination and inspection of visceral organs such as liver, lungs, and kidneys.

The epidemiology and control of hydatidosis is often considered to be a veterinary matter since the disease can be regulated by controlling parasites in animals. However, collaboration between veterinarians and public health workers is essential for the successful control of hydotidosis Permin and Hansen [9]. In Ethiopia, the status of hydatidosis in animals is not well documented and explored. The absence of proper meat inspection procedure, the presence of large population of stray dogs, lack of proper legislation on the control and unhygienic environment contribute significantly to the high prevalence of the disease in Ethiopia, therefore, the objective of the study is

a. To determine the current prevalence of hydatidosis in cattle, sheep and goats slaughtered at Debrezeit, Elfora export abattoir.

b. To assess the direct and indirect economic loss of the country associated with hydatidosis.

\section{Materials and Methods}

\section{Study Area}

The study was conducted at Elfora export abattoir, Debre Zeit from November 2011 to March 2012. The abattoir is a privately owned export abattoir exporting beef, mutton, and goat meat and edible organs like liver, kidneys and brain of sheep and goats to Middle East countries. The study area is found in peri-urban area of Debere-Zeit, Ada'a liben woreda located at about $1.5 \mathrm{~km}$ from the main road to the way to Addis Ababa. Geographically, the area is found the escapement of Great Rift Valley marked by a number of crater lakes situated at $8044^{\prime} \mathrm{N}$ latitude and38058'E longitude at an altitude of $1850 \mathrm{~m}$ above sea level. The mean annual rainfall of the area is $885.4 \mathrm{~mm}$.

The $84 \%$ of the annual rainfall distribution falls down during the long rainy season from June to September and the short rainy season lasts from March to May. The mean annual minimum and maximum temperatures are $14 \mathrm{c} 0 \mathrm{and} 26.30 \mathrm{c} 0$ respectively, with mean relative humidity of $61.3 \%$ CSA [10], NMSA [11]. Farmers in the vicinity of Debere-Zeit town use a mixed farming, crop and animal production and its surroundings have variable and yet representative agro-ecologies of the country. These agro-climatic zones are inhibited with variety of plant and animal species Abera [12].

\section{Study Animals}

The study animals comprise cattle, sheep and goats brought from different parts of the country, mainly in Borana, Arbaminchi, Arsi, Bale and Somali. The origins of slaughtered animals are from different parts of the country and livestock marketing areas like Jinka, Borana and Arbaminchi. Jinka is the central administrative town of south Omo zone and it is found in one of the livestock mixed with crop production districts. Arbaminch is found in Southern nations, nationalities and peoples region. Most of the people in the area are engaged in agriculture both in the highlands and lowlands, ruminants (cattle, sheep and goats) provide milk and meat for human consumption and cash from selling them. The available grazing lands in relation to the animal's population various from place to place in the area, in the highlands there is a small grazing land per head of animal than in the lowland. In the highland farmers use their land both for animal grazing and crop production. The farming system in the area is crop-livestock production system.

\section{Sample Size Determination}

The sample size was determined according to the method described by Thrush field (1995) considering 95\% confidence interval at a desired accuracy level of $5 \%$ and with expected prevalence of $50 \%$.

$$
\mathrm{N}=1.96^{2} \mathrm{P}_{\text {exp }}\left(1-\mathrm{p}_{\exp }\right) / \mathrm{d}^{2}
$$

Where, $\mathrm{N}=$ sample size

Pexp $=$ expected prevalence

$\mathrm{D}=$ desired absolute precision

$\mathrm{P}_{\text {exp }}=50 \%$ and $\mathrm{D}=0.05$ then $\mathrm{N}=384$, in order to increase the accuracy of the test, the sample size was increased to 1134. Therefore, the total sample size studied during the study was 1134 ruminants (203 cattle, 384 sheep and 547 goats) and animals were selected using random sampling method.

\section{Study Design}

Cross-sectional study has been conducted at Elfora export abattoir, Debrezeit. In this cross-sectional study cattle, sheep and 
goats were participated, and clustered into two age groups that are young and adult, based on Steel [13] and Gatenby [14], those that have erupted more than one pair incisor teeth were classified as adult and otherwise young.

\section{Study Methodology}

Cross-sectional abattoir survey was conducted to estimate the prevalence of Hydatidosis in cattle, sheep and goats at Elfora export abattoir, through meat inspection and ante mortem examination $(n=1134)$ '

Ante mortem Examination: During ante-mortem examination, each study animals were given an identification number, age, sex, and origin of animals was recorded; however all the slaughtered animals were males. The age grouping was based on dentition for those which have not erupted permanent incisor teeth, are classified as young, while those with pair or more permanent incisor teeth erupted were classified as adult Alemu and Merkel [15]. The association of body condition scoring and hydatid cyst count was analyzed. Body condition scores of animals were classified in to three as poor (score 1, 2, 3), medium (score 4, 5, 6) and good (score $7,8,9)$ Nicholson and Butterworth [16] after some modification.

Postmortem Examination: The inspection procedures used during the post mortem examination consisted of primary and secondary examinations. The primary examination involved visual inspection and palpation of organs and viscera. The secondary examination involved further incisions in to each organ if a single or more cysts found. Lungs, liver, kidney and heart of each animal were examined grossly. Each organ was also incised once or twice with knife. Whenever and wherever cysts were present, they were removed, put in to polythene bags separately, labeled and then taken to the laboratory for further studies.

Cyst Characterization: Individual cyst was grossly examined for any evidence of degeneration and calcification. Cysts size measurement, cyst counting, cyst fertility and viability determination was also conducted. The size of the diameter of hydatid cyst was measured and classified as large (diameter $>10 \mathrm{~cm}$ ), medium ( 5 to $10 \mathrm{~cm}$ ) and small (diameter $<5 \mathrm{~cm}$ ) Oostburg et al. [17], Kebede et al. [18]. The collected cysts were carefully incised and examined for protoscolices, which looks like white dots on the germinal epithelium, in hydatid fluid so as to classify cysts as fertile or infertile Kebede et al. [18]. Fertile cysts were further subjected to viability test. A segment containing protoscolices was placed on the microscope glass slide and covers with cover slip and observed for amoeboid like peristaltic movement with (40x) objective. For clear vision, a drop of $0.1 \%$ aqueous eosin solution was added to equal volume of protoscolices in hydatid fluid on microscope slide with the principle that viable protoscolices should completely or partially exclude the dye while the dead ones take it up Dalimi et al. [19].

Economic Loss Assessment: The economic loss due to hydatidosis in cattle, sheep and goats slaughtered at Elfora export abattoir in Debre zeit town local market was estimated by considering of condemned visceral organs due to hydatid cyst. By taking into account the average number of ruminants slaughtered and the degree of organ condemnation per annum at Debrezeit, the direct economic loss attributed to hydatidosis was made using the formula indicated by Orgunrinade et al. [1].

ACLLHKC $=(C S R *$ PL1C*L1C $)+\left(C^{*} R^{*}\right.$ PL2C*L2C $)+\left(C^{*}{ }^{*}\right.$ PHC $\left.* H C\right)$ $+\left(\mathrm{CSR}^{*} \mathrm{PKC} * \mathrm{KC}\right)$

Where, ACLLHKC= Annual cost of liver, lung, heart, and kidney condemned

a) $\mathrm{CSR}=$ Average number of cattle slaughtered per year at the abattoir

b) PL1=Percentage of liver condemned

c) L1C=Mean cost of one liver in Debrezeit town

d) PL2C= Percentage of lung condemned

e) L2C $=$ Mean cost of one lung in Debrezeit town

f) $\mathrm{PHC}=$ Percentage of heart condemned

g) $\mathrm{HC}=$ Mean cost of one heart in Debrezeit town

h) $\mathrm{PKC}=$ Percentage of kidney condemned

i) $\quad \mathrm{KC}=$ Mean cost of one kidney in Debrezeit town

The indirect economic loss from carcass weight reduction due to hydatidosis in cattle, sheep and goats were also assessed according to the equation polydorous [20]. The annual cost of carcass weight loss due to hydatidosis (ACC) is estimated by the product of the total number cattle, sheep and goats slaughtered annually (Ns) at Debrezeit Elfora meat factory, the overall prevalence hydatidosis in each species (OP), the carcass weight loss in individual animals due to hydatidosis (CWL) at this abattoir and the average market price of $1 \mathrm{~kg}$ carcass cattle, sheep and goats carcass (AMP) in Debrezeit town and this is represented as

$$
A C C=N s x \text { OPx CWLx AMP }
$$

Therefore, the economic loss from both direct and indirect losses equals the sum of the two. i.e. ACLLHKC + ACC

\section{Data Analysis}

Data that were generated from post mortem inspection was recorded in the Micro Soft Excel spread sheet 2007 program. Descriptive statistics such as percentage was calculated and prevalence of hydatidosis was defined as the proportion of condemned organs to the total number of organs inspected. The variation between the condemnation rates of lungs, livers, heart and kidney of cattle, sheep and goats of different age groups, body condition and origin was evaluated by Pearson's chi square $\left(\mathrm{X}^{2}\right)$ test and differences were regarded statistically significant if $\mathrm{p}-$ value is less than 0.05 .

\section{Result}

\section{Prevalence of Hydatidosis in Slaughtered Ruminants}

In current study a total of 1134 ruminants consisting of 203 cattle, 384 sheep and 547 goats were examined for the prevalence 
of hydatid cyst infection. Out of these total examined animals 87 (42.86\%), $27(7.03 \%)$ and 24 (4.39\%) cattle, sheep and goats, respectively were found infected with hydatid cyst (Table 1). Out of 203 examined cattle 84 (41.4\%), 70 (34.5), 6 (3\%) and 5 (2.5) lung, liver, kidney and heart, respectively were found infected with hydatid cyst. On the other hand, out of 384 examined sheep $24(3.3 \%)$ lung, $19(2.6 \%)$ liver, $2(0.2 \%)$ kidney and $0(0 \%)$ heart were found infected with hydatid cyst, out of 547 examined goats 18 (6.3\%), 14 (4.9\%), 1(0.5\%) and 0(0\%) lung, liver, kidney and heart were found infected respectively (Table 2).

Table 2: The distribution of hydatid cyst in different organs in cattle, sheep and goats slaughtered at Debrezeit Elfora Export abattoir.

\begin{tabular}{|c|c|c|c|c|c|c|c|c|c|c|c|c|}
\hline \multirow{3}{*}{$\begin{array}{l}\text { Species } \\
\text { of } \\
\text { animals }\end{array}$} & \multirow{2}{*}{\multicolumn{2}{|c|}{$\begin{array}{l}\text { No. of animal } \\
\text { infected }\end{array}$}} & \multicolumn{10}{|c|}{ Infected organs } \\
\hline & & & \multicolumn{2}{|c|}{ lung } & \multicolumn{2}{|c|}{ liver } & \multicolumn{2}{|c|}{ kidney } & \multicolumn{2}{|c|}{ Heart } & \multicolumn{2}{|c|}{ Total } \\
\hline & No. & $\%$ & No. & $\%$ & No. & $\%$ & No. & $\%$ & No. & $\%$ & No. & $\%$ \\
\hline Cattle & 87 & 42.86 & 84 & 41.4 & 70 & 34.5 & 6 & 3.0 & 5 & 2.5 & 126 & 81.4 \\
\hline Sheep & 27 & 7.03 & 24 & 3.3 & 19 & 2.6 & 2 & 0.2 & 0 & 0 & 103 & 6.2 \\
\hline Goats & 24 & 4.39 & 18 & 6.3 & 14 & 4.9 & 1 & 0.5 & 0 & 0 & 9 & 11.7 \\
\hline Total & 138 & 54.28 & 126 & 51 & 103 & 42 & 9 & 3.7 & 5 & 2.5 & 5 & 100 \\
\hline
\end{tabular}

This showed that there is a significant association $(\mathrm{P}<0.05)$ between species of animals and the prevalence of hydatidosis. A total of 126 lungs, 103 livers, 9 kidneys and 5 hearts were found positive for hydatid cyst infection in slaughtered ruminants at the abattoir in general. In this study the prevalence of hydatidosis in lungs, liver, kidney and heart of young and adult ruminants slaughtered

at Debrezeit Elfora export abattoir were 23.8, 20.4, 11.1, 20.0 and $76.2,79.6,88.9,80$ respectively which is not significant $(\mathrm{P}>0.05)$ (Table 3). Furthermore, a prevalence of hydatidosis in organs of slaughtered ruminants were also determined by considering body condition as a potential risk factor and this has a high significant difference $(\mathrm{P}<0.05)$ (Table 4).

Table 3: Prevalence of hydatidosis in relation to age as a potential risk factor in organs of ruminants slaughtered at Debrezeit Elfora Export abattoir.

\begin{tabular}{|c|c|c|c|c|}
\hline \multirow{2}{*}{ Organs } & \multicolumn{5}{|c|}{ Risk factor (age) } \\
\cline { 2 - 5 } & No. of positive & Prevalence (\%) & No. of positive & Adult \\
\cline { 2 - 5 } & 30 & 23.8 & 96 & 76.2 \\
\hline Lung & 21 & 20.4 & 82 & 79.6 \\
\hline Liver & 1 & 11.1 & 8 & 88.9 \\
\hline Kidney & 1 & 20 & 4 & 80 \\
\hline Heart & & & & \\
\hline
\end{tabular}

\section{Note:}

a. Age*lung, $x^{2}=0.23 a, D F=1, p=0.631$ Age *kidney, $x^{2}=0.640 a, D F=1, p=0.424$

b. Age *liver, $x^{2}=0.200 a, D F=1, p=0.654$ Age *heart, $x^{2}=0.013 a, D F=1, p=0.908$

Table 4: prevalence of hydatidosis in relation to body condition as the potential risk factor in the organs of ruminants slaughtered at Debrezeit Elfora Export abattoir.

\begin{tabular}{|c|c|c|c|c|c|c|c|c|}
\hline \multirow{3}{*}{ Organs } & \multicolumn{6}{|c|}{ Risk factor(body condition) } & \multirow{2}{*}{\multicolumn{2}{|c|}{ Total }} \\
\hline & \multicolumn{2}{|c|}{ Poor } & \multicolumn{2}{|c|}{ medium } & \multicolumn{2}{|c|}{ good } & & \\
\hline & No. & $\%$ & No. & $\%$ & No. & $\%$ & No. & $\%$ \\
\hline Lung & 23 & 18.25 & 9 & 7.15 & 94 & 74.60 & 126 & 100 \\
\hline Liver & 25 & 24.27 & 7 & 6.80 & 71 & 68.93 & 103 & 100 \\
\hline Kidney & 1 & 11.11 & 2 & 22.22 & 6 & 66.67 & 9 & 100 \\
\hline Heart & 2 & 40 & 0 & 0 & 3 & 60 & 5 & 100 \\
\hline
\end{tabular}

a. Body condition *lung, $x^{2}=103.608 a, D F=2, p=0.000$

b. Body condition *liver $x^{2}=157.926 a, D F=2, p=0.000$

c. Body condition *kidney $x^{2}=10.704 a, D F=2, p=0.005$

d. Body condition *heart $x^{2}=20.90 a, D F=2, p=0.000$ 


\section{Cyst Characterization}

Out of the total of 982 cysts recorded in the organs of slaughtered cattle 390(39.7\%) small, 134(34.0\%) medium and $159(15.9 \%)$ large cysts were found. On the other hand, out of 82 total cysts recorded in sheep 31(37.8\%) small, 35(42.7\%) medium and $16(19.5 \%)$ large cysts were found, whereas of 81 cysts recorded in goats23 (28.4\%) small, 19 (23.5\%) medium and 16(19.6\%) large were found. The highest numbers of the cyst were recorded in the lungs of cattle 558 and have $56.8 \%$ average of occurrence in this organ. In this study a total of 1145 cysts were found from the slaughtered ruminant organs; $657(57.38 \%)$ lung, 467(40.78\%) liver, $13(1.14 \%)$ kidneys, and $8(0.070 \%)$ hearts of slaughtered ruminants in general. The cyst were collected from different infected organs and subjected to fertility and viability test. From the total cysts examined 696(60.79\%) were fertile, 263(22.97\%) were sterile and 194(16.94\%) were calcified. Out of 696 fertile cysts in slaughtered ruminants 531(76.29\%) were viable and 165(23.71\%) were non-viable (Table 5).

Table 5: Cyst size and count in relation to involved organs in infected ruminants slaughtered at Debrezeit Elfora Export Abattoir.

\begin{tabular}{|c|c|c|c|c|c|c|c|c|c|c|}
\hline \multirow{3}{*}{$\begin{array}{l}\text { Animal } \\
\text { species }\end{array}$} & \multirow{3}{*}{ Organs } & \multirow{3}{*}{$\begin{array}{l}\text { No. of cyst } \\
\text { examined }\end{array}$} & \multicolumn{6}{|c|}{ Cyst count in terms of size } & \multirow{2}{*}{\multicolumn{2}{|c|}{ Total }} \\
\hline & & & \multicolumn{2}{|c|}{ small } & \multicolumn{2}{|c|}{ medium } & \multicolumn{2}{|c|}{ Large } & & \\
\hline & & & No. & $\%$ & No. & $\%$ & No. & $\%$ & No. & $\%$ \\
\hline \multirow{4}{*}{ Cattle } & Lung & 558 & 249 & 25.4 & 196 & 20 & 113 & 11.5 & 558 & 56.8 \\
\hline & Liver & 406 & 224 & 22.8 & 136 & 13.8 & 46 & 4.7 & 406 & 41.3 \\
\hline & kidney & 10 & 8 & 0.8 & 2 & 0.2 & 0 & 0 & 10 & 1.0 \\
\hline & heart & 8 & 8 & 0.8 & 0 & 0 & 0 & 0 & 8 & 0.9 \\
\hline \multirow{4}{*}{ Sheep } & Lung & 55 & 21 & 25.6 & 22 & 26.8 & 12 & 14.6 & 55 & 67.1 \\
\hline & Liver & 25 & 8 & 9.8 & 13 & 15.9 & 4 & 4.9 & 25 & 30.5 \\
\hline & kidney & 2 & 2 & 2.4 & 0 & 0 & 0 & 0 & 2 & 2.4 \\
\hline & heart & 0 & 0 & 0 & 0 & 0 & 0 & 0 & 0 & 0 \\
\hline \multirow{4}{*}{ Goat } & Lung & 44 & 12 & 14.8 & 23 & 28.4 & 9 & 11.1 & 44 & 54.3 \\
\hline & Liver & 36 & 10 & 12.4 & 19 & 23.5 & 7 & 8.6 & 36 & 44.4 \\
\hline & kidney & 1 & 1 & 1.2 & 0 & 0 & 0 & 0 & 1 & 1.3 \\
\hline & heart & 0 & 0 & 0 & 0 & 0 & 0 & 0 & 0 & 0 \\
\hline \multirow{3}{*}{ Total } & Cattle & 982 & 489 & 49.8 & 334 & 34 & 159 & 16.2 & 982 & 100 \\
\hline & Sheep & 82 & 31 & 37.8 & 35 & 42.7 & 16 & 19.5 & 82 & 100 \\
\hline & goat & 81 & 23 & 28.4 & 42 & 51.9 & 16 & 19.8 & 81 & 100 \\
\hline
\end{tabular}

\section{Economic Loss Assessment}

In this study the direct economic loss due to infection by hydatid cysts in cattle, sheep and goats were estimated. The direct economic loss refers to losses due to condemnation of visceral organs infected with hydatid cyst infection. The current study refers that the lungs and the livers are the two most common organs usually condemned by hydatid cyst infection, Even though the kidneys and hearts were also involved. The average annual number of slaughtered cattle, sheep and goats at Debrezeit Elfora export abattoir was 3961, 445117, and 449592 respectively and the average number of annually condemned organs which includes lungs, livers, kidneys and hearts due to hydatidosis were 1143,02 , 51, and 6 for cattle; 1016, 894, 10 and 2 for sheep and 2298, 2260, 8 and 2 for goats respectively (Table 6).

Table 6: Condition of hydatid cyst in different organs of infected ruminants slaughtered at Debrezeit Elfora export abattoir.

\begin{tabular}{|c|c|c|c|c|c|c|c|c|c|c|c|}
\hline \multirow{3}{*}{ Organs } & \multirow{3}{*}{$\begin{array}{l}\text { No. of cyst } \\
\text { examined }\end{array}$} & \multicolumn{6}{|c|}{ Fertile } & \multirow{2}{*}{\multicolumn{2}{|c|}{ sterile }} & \multirow{2}{*}{\multicolumn{2}{|c|}{ calcified }} \\
\hline & & \multicolumn{2}{|c|}{ Total number } & \multicolumn{2}{|c|}{ Viable } & \multicolumn{2}{|c|}{ Non-viable } & & & & \\
\hline & & No. & $\%$ & No. & $\%$ & No. & $\%$ & No. & $\%$ & No. & $\%$ \\
\hline Lung & 657 & 436 & 38. & 344 & 79 & 92 & 21 & 154 & 13.45 & 80 & 7 \\
\hline Liver & 467 & 260 & 23 & 187 & 72 & 73 & 28 & 109 & 9.52 & 114 & 10 \\
\hline Kidne & 13 & 0 & 0 & 0 & 0 & 0 & 0 & 0 & 0 & 0 & 0 \\
\hline Heart & 8 & 0 & 0 & 0 & 0 & 0 & 0 & 0 & 0 & 0 & 0 \\
\hline Total & 1145 & 696 & 60.79 & 531 & 76.29 & 165 & 23.24 & 263 & 22.97 & 194 & 17 \\
\hline
\end{tabular}

In this study, the annual direct economic loss due to cost of condemned organs infected by hydatid cyst in cattle was obtained by computation of average annually slaughtered cattle (3961) by the percentile of condemned organs of lungs (28.86\%), liver $(22.77 \%)$, kidney $(1.29 \%)$ and heart $(0.15 \%)$ which is $71570.71 \mathrm{ETB}$.
Computed direct economic losses from condemned organs of cattle, sheep and goats were estimated totally be 119591.3 ETB. This was calculated from the current mean retailer market price of cattle lung (17ETB), liver (57ETB), kidney (12.5ETB) and heart (15ETB) and sheep and goat lung (5), liver (10), kidney (2.5) and heart (2.75ETB) 
in Debrezeit town. Indirect economic loss due to hydatidosis affects carcass weight gain of cattle by $5 \%$ loss, for sheep and goats by $2.5 \%$ loss Polydorous [20]. In the current study carcass weight loss due to hydatid cyst was estimated by using average annual number of slaughtered cattle (3961), average carcass weight loss (135kg), over all prevalence of hydatidosis in cattle (42.86\%), 5\% weight loss and the current price of $1 \mathrm{~kg}$ beef in Debre zeit town.

As a result, economic loss of 622417.1ETB per annual was estimated. By using the same procedure, average annual of

Table 7: Number of slaughtered ruminant and organs condemned at Debrezeit Elfora export abattoir.

\begin{tabular}{|c|c|c|c|c|c|c|c|c|c|}
\hline \multirow{3}{*}{$\begin{array}{l}\text { Species of } \\
\text { animals }\end{array}$} & \multirow{3}{*}{$\begin{array}{c}\text { No. of } \\
\text { slaughtered } \\
\text { animals }\end{array}$} & \multicolumn{8}{|c|}{ Condemned organs due to hydatid cyst } \\
\hline & & \multicolumn{2}{|c|}{ Lung } & \multicolumn{2}{|c|}{ liver } & \multicolumn{2}{|c|}{ Kidney } & \multicolumn{2}{|c|}{ Heart } \\
\hline & & No. & $\%$ & No. & $\%$ & No. & $\%$ & No. & $\%$ \\
\hline Cattle & 3961 & 1143 & 28.86 & 902 & 22.77 & 51 & 1.29 & 6 & 0.15 \\
\hline Sheep & 445117 & 1016 & 0.21 & 894 & 0.20 & 10 & 0.002 & 2 & 0.00045 \\
\hline Goats & 449592 & 2298 & 0.51 & 2260 & 0.50 & 8 & 0.002 & 2 & 0.0004 \\
\hline
\end{tabular}

Source: Meat inspection record during the survey period of Debrezeit Elfora export abattoir (2011- 2012).

Table 8: Computed economic loss.

\begin{tabular}{|c|c|c|c|}
\hline \multicolumn{2}{|c|}{ Variables } & Computed values & Ethiopian Birr(ETB \\
\hline \multirow{6}{*}{ Cattle } & Lung & 3961x28.86\%x17ЕTB & 19433.46 \\
\hline & Liver & 3961×22.77\%x57 ЕТВ & 51409.42 \\
\hline & Kidney & 3961x1.29\%xx12.5 ЕТВ & 638.71 \\
\hline & Heart & $3961 \times 0.15 \%$ x15ЕТВ & 89.12 \\
\hline & Carcass & 3961x42.86\%x5\%x136x54ЕTВ & 622417.1 \\
\hline & \multicolumn{2}{|c|}{ Sub total } & 693987.81 \\
\hline \multirow{6}{*}{ Sheep } & Lung & $445117 \times 0.21 \% \times 5$ ETB & 4673.73 \\
\hline & Liver & $445117 \times 0.20 \%$ x10ЕТВ & 4451.17 \\
\hline & Kidney & $445117 \times 0.002 \times 2.5$ ETB & 22.3 \\
\hline & Heart & $445117 \times 0.00045 \times 2.75$ ЕТВ & 4.9 \\
\hline & Carcass & $445117 \times 7.03 \% \times 2.5 \% \times 13.5 \times 56$ ETB & 591314.6 \\
\hline & \multicolumn{2}{|c|}{ Sub total } & 600465.2 \\
\hline \multirow{6}{*}{ Goat } & Lung & $449592 \times 0.51 \%$ x5ЕТВ & 11464.6 \\
\hline & Liver & $449592 \times 0.50 \%$ x10ЕТВ & 22479.6 \\
\hline & Kidney & $449592 \times 0.002 \% \times 2.5$ ЕТВ & 22.5 \\
\hline & Heart & $449592 \times 0.0004 \% \times 2.75$ ЕTВ & 4.9 \\
\hline & Carcass & $449592 \times 4.39 \% \times 2.5 \% \times 13.5 \times 56$ ЕTB & 223818.59 \\
\hline & \multicolumn{2}{|c|}{ Sub total } & 257790.19 \\
\hline \multicolumn{3}{|c|}{ Grand Total } & 1552243.2 \\
\hline
\end{tabular}

Source: Meat inspection record during the survey period of Debrezeit Elfora export abattoir (2011- 2012)

\section{Discussion}

The study revealed that hydatidosis was highly prevalent in cattle and slightly prevalent in sheep and goats slaughtered at Debrezeit Elfora Export Abattoir. The high occurrence of infection in the intermediate host, suggests the presence of environmental contamination with the eggs of the adult tape worm Echinococcus granulosus. The prevalence of $42.86 \%, 7.03 \%$ and $4.39 \%$ of hydatidosis in cattle, sheep and goats respectively, obtained from this study are relatively lower than the findings of certain works in slaughtered sheep (445117), over all prevalence of hydatidosis in sheep $(7.03 \%)$, average carcass weight $(13.5 \mathrm{~kg}), 2.5 \%$ weight loss and the current value of $1 \mathrm{~kg}$ chevon (56ETB) economic loss was incurred in through carcass yield loss in both of sheep and goats was calculated to be ETB 815133.19. Therefore, the total estimated direct and indirect economic loss of cattle, sheep and goats slaughtered at Debre zeit Elfora Export abattoir due to hydatidosis was estimated to be the sum of the direct and indirect loss from cattle, sheep and goats, which is $1552243.2 \mathrm{ETB}$ per year (Table 7 \& 8). 
This variation in prevalence rate could be due to the difference in sample size, selection of the study animals, the origin of the animals brought for slaughter and the strain difference of Echinococcus granulosus were shown to have difference in their geographical distribution Angus [28]. In addition other factors such as difference in socio-cultural structures and the degree of close association among the society, livestock and dogs are important factor that have been responsible for high prevalence of hydatidosis elsewhere Macpherson [29]. Generally, the density, infectivity and availability of the eggs in the environment, the feeding behavior of the intermediate host, together with the external environment have a vital role in determining the dynamics of transmission of parasite FAO [30]. In general, in present study, the liver and lugs are the most commonly affected organs in cattle sheep and goats.

This is in fundamental agreement with literature, which states that hydatid cysts are most commonly found in the liver and lungs of ungulates Soulsby [3], Urquhart et al. [31], Yilma Jobre et al. [23], Getaw et al. [32], [33,34]. This could be justified by the fact that lungs and liver posses the first greater capillary fields which acts as partial barriers for the ingested oncosphere, Which adopt the portal vein route and primarily negotiates the hepatic and the Pulmonary filtering action sequentially before any other peripheral organ is invaded Matosain [35]. In this work percent involvement of the lungs is higher than the liver in all the three species; cattle, sheep and goats. Literature reveals that in older cattle and sheep, the liver sinusoids permits the embryos to traverse the sinusoids and reach the lungs. It is also possible for embryos to enter the hepatic circulation and be carried, via the thoracic duct and heart, to the lungs so that lungs will be infected before or instead of the liver Gracy [36].

The kidneys and hearts are the least affected organs. Similar findings were also obtained by various workers and it is indicated that liver and lungs are the most commonly affected organs with hydatid cyst due to the reason that they are the first capillary fields encountered by the blood borne oncospheres of the parasite Angus [28]. However, development of hydatid cyst occurs occasionally in other organs and tissues when the oncosphere escape in systemic circulation Urquhart et al. [31]. Higher number of large and medium sized cyst were found in lung than in liver and more number of calcified cyst were found in the liver than of the lung. This observati Habtamu [24,37] who confirmed that larger size of cyst in the lungs was due to its relative softer consistency Smith [38]. In very yielding tissues of peritoneal cavity where the growth of the hydatid cysts were almost unrestricted, it may grow to an immense size with several liters of fluids bearing daughter cysts, brood capsule and hydatid sands Soulsby [39].

The higher percentage of calcified cyst in the liver could be attributed to a higher reticulo endothelial and connective tissue reaction of organs. It is not unlikely that larger number of embryos is killed in these organs, the site of destruction and lesion usually healed by fibrosis and calcification Smith [38]. Relatively higher percentage of fertile cyst $(60.79 \%)$ in cattle was obtained than the percentage of sterile (22.97\%). In Britain up to $90 \%$ of the total cysts of cattle may be sterile although in some countries like South Africa (96.9\%), Belgium (94.2\%), and Rhodesia (86.5\%) uncalcified cysts were fertile. The variation in fertility could be accounted to the strain difference of Echinococcus Arene [39,40]. The fertility rate was higher among the cyst of lung than the liver in all the three species of animals. This is an agreement with the result of other workers and it has been stated that the relatively softer consistency of the lung allows easier development of the lung pressure cysts and fertility of hydatid cysts may show a tendency to increase with advancing age of the host Hubbert et al. [2], Himonas [41], this may be related with reduced immunological capability of the host at higher old age of infection.

The fertility rate among the four organs examined in slaughtered domestic ruminants are variable, it was higher for lung and liver (38.08\% and $13.45 \%)$, respectively than for kidney and heart $(0 \%$ and $0 \%$ ), respectively. In this study, the fertility rate of uncalcified hydatid cyst in the lung (38.08\%) is higher when compared to liver $(13.5 \%)$ and there is significant difference $(\mathrm{P}<0.05)$ among the organs. Similar results are recorded by other workers Fikre [42] and Habtamu [24]. This variation in fertility rate among the different organs of animal species is probably due to difference in strains Echinococcus granulosus Soulsby [39]. The higher fertility rate of hydatid cyst in lungs and livers show that the slaughtered ruminants are the most intermediate host for the maintenance of the life cycle of the parasite, which further facilitated by the fact that sheep and goats are slaughtered at homes and back yard, as a result of which veterinary meat inspection is particularly impossible.

Moreover, it have been indicated that ovine strain of Echinococcus granulosus imposes a tremendous effect on health hazard in respect to human population and the presence of fertile cyst on cattle of apparent ovine strain may constitute an additional public health problem Moidrige [43]. In this study hydatidosis was found incur financial loss that is estimated to be 1552243.2 ETB to cattle, sheep and goats industry per year. Previous workers have also estimated the annual financial losses associated with hydatidosis from other parts of the country. For example; Yilma reported financial loss about 813,526.46 ETB from Debrezeit abattoir; Moges reported financial loss of 131,190.45ETB from Jimma, While Bersisa [26] and Getaw et al. [32, 44-46] reported financial loss of 77, 587.02 ETB and 5869.80USD attributable to bovine hydatidosis from Nekemte and Gonder abattoir respectively [47-50]. The figure obtained in this study varies from the others which may be due to number of animals slaughtered and variation in the retail market price of the affected organs.

\section{Conclusion and Recommendations}

The aim of the present study was to determine the prevalence and the economic significance of hydatidosis in slaughtered ruminants at Debrezeit Elfora export abattoir [51-56]. Hydatidosis is the highly prevalent parasitic disease found in ruminant intermediate host including cattle (42.86\%), sheep (7.03\%) and goats $(4.39 \%)$ slaughtered at Debrezeit Elfora export abattoir, Ethiopia [57-59]. This disease causes a significant economic loss 
directly by causing organ condemnation and indirectly by carcass weight loss gain which estimated totally be 1552243 .2ETB $[60,61]$. Improper disposal of carcass (organ), increased population of stray dogs, lack of proper meat inspection and lack of appropriate legislations for the control of the disease are the most important factors that increase the transmission of the disease. Based on the above conclusive points the following recommendations are forwarded:

a. Regular deworming of pet dogs and control of stray dogs,

b. Meat should be properly inspected by sufficient number of inspectors at the abattoir,

c. Public awareness creation about the transmission and control of the disease and its public health significance,

d. Proper disposal of carcass either by burning or burring and avoiding the habit of giving offal to dogs,

e. Collaboration between veterinarians and public health workers in the prevention and control of the disease is mandatory,

f. Proper food hygiene, and personal hygiene especially, those having close contact with pets.

\section{References}

1. Ogunrinade A, Adegoke GO (1982) Bovine Fasciolosis in Nigeria, Intercurrent Parasitic and Bacterial Infection. Tropical Animal Health Production 14(2): 121-125.

2. Hubbert WT, Culloch WF, Scnurren Beger AA (1995) Diseases Transmitted from Animals to man. Sixth (Edn.). Choreler C, Thomas Publisher, Spring Field Illinosis, USA, pp. 682-692.

3. Soulsby EJL (1986) Helminthes, Arthropod and protozoa of domestic animals. $7^{\text {th }}$ (Edn.). Lea and Fediger, Philadelphia, US, pp. 211- 225.

4. Martinma EA (2007) Oxford Concise Medical Dictionary. $7^{\text {th }}$ (Edn.). Oxford University Press, India, Bungar, pp. 342-343.

5. Urquhart GM, Armour J, Duncan JL, Dunn AM, Jennings FW (1995) Veterinary Parasitology. $2^{\text {nd }}$ (Edn.). Blackwell Publishing, USA, pp. 122129.

6. Eckert J, Rausch RL, Gemmell MAG, Raudoux P, Kamiya M, et al. (2001) Epidemiology of Echinococonccus multilocularis, Echinococcus vogeli and Echinococcus oligarthus. In WHO/OIE manual on echinococcosis in humans and animals: a public health problem of global concern; edited by Eckert J, Gemmel MA, Meslin FX, Pawlowsk, ZS, pp. 167.

7. Tor M, Atasaliki A, Altuntas N, Sllue Senol T, Kir A, Baran R (2000) Review of Cases with cystic hydatid lung disease in a territory referral hospital located in an endemic region: a 10 years experience. Department of Pulmonary Medicine, Istanbul, Turkey, 67: 539-542.

8. Thompson RC, Memanus DP (2001) Aetiology : Parasites and Lifecycles: In: WHO/OIE Manual on Echinocosis in humans and animals a public health problems of global concern edited by Eckert J, Gemmen MA, Meslin FX, Pawlowski, ZS, Japan, pp.9-15.

9. Permin A, Hansen JW (1994) Review on Hydatidosis.

10. (2003) CSA Ethiopian sample enumeration, 2002/2002. Central Statistical Authority, FDRE, Ethiopia.

11. (2003) NMSA, National meteorology service agency Addis Ababa, Ethiopia.

12. Abera G (2007) prevalence and economic significance of bovine Fasciolosis and hydatidosis, DVM Thesis, Addis Ababa, Ethiopia, p. 3-9.
13. Steele M, Mith AJ (1996) Goats (Tropical Agriculturalist). MacMillan Education Ltd. London, ISBN 13, pp. 160.

14. Gatenby RM (1991) Sheep in tropical African Agriculturalist, Macmillan, TCTA, pp. 6-10.

15. Alemu Y, Merkel RS (2008) 0: Sheep and Goat production hand book for Ethiopia pp. 13.

16. Nicholson MJ, Butter worth MH (1986) A guide to condition scoring of zebu cattle. ILCA, Addis Ababa, Ethiopia.

17. Oostburg BFJ, Verde MA, Bergen AE, (2000) The occurrence of polycystic echinococcosis in Suriname. AnnTrop Med Parasito 94(3): 247-252.

18. Kebede W, Hagos A, Girma Z (2009) Echinococcosis/hydatidosis prevalence, economic and public health significance in Tigray region, North Ethiopia. Trop Anm Health Prod 41(6): 865-871.

19. Dalimi A, Motamedi G, Hosseini M, Mohammadian B, Malaki H, et al. (2002) Echinococcosis/Hydatidosis in western Iraq. Vet Parasitology 105(2): 161-171.

20. Polydorou K (1981) Animal health and economics. Case study: echinococcosis with reference to Cyprus. Bul Int Epz 93: 981-992.

21. Alemayehu L (1990) The prevalence of hydatidosis in cattle, sheep and goats, Echinococcus granulosus in dogs in Arsi Administrative region, DVM Thesis, AAU, FVM , DZ, Ethiopia pp. 7.

22. Fekadu, OA (1997) Study on prevalence and economic significance of hydatidosisin ruminants and Echinococcus granulosus in dogs. DVM Thesis. Addis AbabaUniversity, Faculty of Veterinary Medicine, Debre Zeit, Ethiopia, pp. 49.

23. Jobre Y, Lobago F, Tiruneh R, Abebe G, Dorchies Ph (1996) Hydotidosis in three selected regions in Ethipia: an assessment trail units prevalence, economic and public health impact, Addis Ababa University, Faculty of Veterinary Medicine, Debrezeit, Ethiopia 11: pp.797-804.

24. Habtamu A (2010) Study on prevalence and economic loss of hydatidosis in slaughtered ruminants at Adama abattoir. DVM Thesis, Collage of Health Science, SVM, AAU, pp. 11.

25. Getahun D (1987) Incidence of bovine echinococcosis at Melgue Wondo abattoir and therole of dogs, jackals and hyena in the transmission around Awassa and Wondogenet. DVM Thesis. Addis Ababa University, Faculty of Veterinary Medicine, Debre Zeit, Ethiopia, pp. 21.

26. Bersisa K (1994) Hydatidosis in Nekemte: Prevalence in slaughtered cattle and sheep, estimated economic loss and incidence in stray dogs, DVM Thesis, FVM, AAU, DZ, Ethiopia, pp. 23.

27. Yilkal A (1989) Hydatidosis in cattle, sheep, pigs and cysticeccus tenuicollis in sheep around Dessie and the efficacy of Hagenia Abyssinia (konso) on Taenia hydatigena. DVM Thesis, FVM, AAU, Debrezeit, Ethiopia.

28. Angus $\mathrm{T}$ (1987) Veterinary Helminthology In $2^{\text {nd }}$ (Edn.). William Henmann medical book Ltd, London, UK, pp. 332.

29. Macpherson C NL, Zeyhle E, Roming T (1985) An Echinococcus plot control program for North West Turkan Kenya Ann Trop Med Parasite 78: 188-192.

30. (1994) FAO Guide line for training, food and agricultural organizations, Rome, Italy, pp. 19-20.

31. Urquhart GM, Armour J, Duncan JL, Dunn AM, Jennings FW (1988) Veterinary parasitology, Longman, UK, pp. 228.

32. Getaw A, Beyene D, Ayana D, Megersa B, Abunna F (2010) Hydatidosis: Prevalenceand its economic importance in ruminants slaughtered at Adama municipalabattoir, Central Oromia, Ethiopia. Acta Tropica 113(3): 221-225.

33. Ibrahim MM (2010) Study of cystic echinococcosis in slaughtered animals in $\mathrm{Al}$ Baha region, SaudiArabia: interaction between some biotic and abiotic factors. Acta Tropica, 113(1): 26-33. 
34. Kebede N (2010) A retrospective survey of bovine hydatidosis in three abattoirs of Amhara National Regional State, northwestern Ethiopia. Trop Anim Health Prod 42(3): 323-325.

35. Matosain RM (1977) Hydatidosis, A global problem of increasing importance. Bul WHO, Balkans 55: 499-507.

36. Gracy JF (1994) Textbook of meat hygiene. $6^{\text {th }}$ (Edn.). Beilleir Tindall, London, pp. 517.

37. Bereket T (2008) Prevalence and economic impact of bovine hydatidosis at AA abattoir, DVM Thesis, FVM, DZ, Ethiopia, pp. 12.

38. Smith JD (1987) Changing Concepts in the Microecology, Macroecologyand Epidemiology of Hydatid Disease. In Geerts S, Kumar V, Brand J (Eds.), Helmint Zoonoses, pp. 1-11.

39. Soulsby EJ (1982) Helminthes, Arthropods and Protozoas of Domesticated Animals. $7^{\text {th }}$ (Edn.). Lea and Fediger, Philadelphia, US, pp. 119- 125.

40. Arene FO I (1985) Prevalence of hydatid cysts in domestic livestock in the Niger Delta. Trop Anim Hlth Prod 17(1): 3-5.

41. Himonas C, (1987) The fertility of the hydatid cyst in food animal's helminthes zoonosis Masrtinus, Nijjh publisher, Nederland. FVM, AAU, DZ, Ethiopia, pp. 13.

42. Fikre L (1994) Echinococcosis in konso: an assessment of its prevalence, economic and public health importance, DVM Thesis, FVM, AAU, DZ Ethiopia, pp. 10.

43. Moidrage R, Ian MI (1981) Disease of cattle in the tropics, economic and zoonotic relevance, Martinus Nijnoff publisher, Belgium, pp. 662.

44. Beers MA, Porter RS, Jones TV, Kaplan JL, Berkwits M (2006) The MerckBailleir Tindall, London, UK, pp. 809.

45. Boden E (1998) Black's Veterinary Dictionary 19 ${ }^{\text {th }}$ (Edn), Jaypee Brothers Medical Publishers, New Delhi, India, pp. 261-262.

46. (2004) CSA (Central Statistics Authority), Ethiopian Agricultural Sample Survey Report on live-stock, Poultry and Beehives Populations, CSA, Addis Ababa, Ethiopia.

47. (2006) Drug Administration and Control authority of Ethiopia (DACA) Standard Treatment Guidelines for Veterinary Practice. $1^{\text {st }}($ Edn.). Camper printing house, Ethiopia, pp. 43-44.
48. Gracey JF, Collins CS, Huey RJ (1999) Meat Hygiene. $10^{\text {th }}$ (Edn.). W.B Saunders Company LTD, London. pp. 660-669.

49. Harvey RA, Champe PC, Fisher BD (2007) Lippincott's Illustrated Reviews: Microbiology. $2^{\text {nd }}($ Edn.). Lippincott Williams and Wilkins, Philadelphia, Pennsylvania, US, pp. 227-228.

50. Jones T C, Hunt RC, and King, NW (2006): Veterinary Pathology. $6^{\text {th }}$ (Edn.). Blackwell Publishing, USA, pp. 655-656.

51. Jubb KVF, Kennedy, PC, Palmer N (1993) Pathology of Domestic Animals 2: $4^{\text {th }}($ Edn.). Elsevier, New Delhi, India, pp. 290-292.

52. Mandal SC (2006) Veterinary Parasitology at a glance. $1^{\text {st }}$ (Edn.), Charbagh, Lucknow, India, pp. 153-157.

53. Mims C, Dockers HM, Goering RV, Roitt I, Wakelin D, et al. (2004) Medical Microbiology. $3^{\text {rd }}$ (Edn.). Elsevier Mosby, Luck now, India, PP. 338-339.

54. Moges M (2003) Study on bovine fasciolosis and hydatidosis at Jimma, Western Ethiopia, DVM, Thesis AAU, FVM, DZ, Ethiopia, pp. 10.

55. Paniker CK (2007) Text Book of Medical Parasitology. $6^{\text {th }}$ (Edn.). Jayple Brothers Medical Publishers, New Delhi, India, pp. 150-155.

56. Sastery, GA, Ramarao P (2001) Veterinary Pathology. $10^{\text {th }}$ (Edn.). CBS Publishers and Distributors, New Delhi, India, pp. 723-724.

57. Tamene M (1986) A preliminary study on echinococcosis/hydatidosis of livestock (cattle,sheep and dogs) in Gondar administrative region. DVM Thesis. Addis Ababa University, Faculty of Veterinary Medicine, Debre Zeit, Ethiopia, pp.286.

58. Taylor MA, Coop Rl, Wall, RL (2007) Veterinary Parasitology. $3^{\text {rd }}$ (Edn.), Blackwell publishing, Iowa, US, pp. 337-339.

59. Thrusfield M (1995) Veterinary Epidemiology. $2^{\text {nd }}$ (Edn.). Edinburgh, Black well, UK, pp. 178-182.

60. Tsegaye T (1995) Epidemiology of bovine fasciolosis and hydatidosis in Debre Berhanregion. DVM Thesis FVM, Debre Zeit, Ethiopia, pp. 56.

61. Zajac AM, Conboy GA (2006) Veterinary Clinical Parasitology. $7^{\text {th }}$ (Edn.). Blackwell publishing, State Avenue, US, pp. 60.

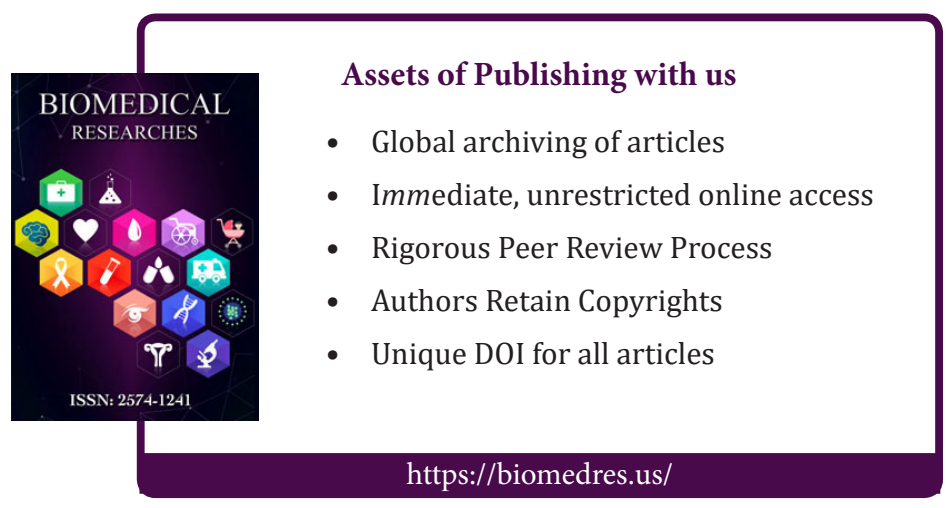

